\title{
Aberrant expression of miR-663 and transforming growth factor- $\beta 1$ in nasal polyposis in children
}

\author{
HAILING YU ${ }^{1}$, JIANBAO JU ${ }^{2}$, JINGDONG LIU ${ }^{3}$ and DA LI ${ }^{1}$ \\ ${ }^{1}$ Department of Otolaryngology, The Women and Children's Hospital of Qingdao; \\ ${ }^{2}$ Department of Otolaryngology, The Affiliated Hospital of Qingdao University; ${ }^{3}$ Department of Medicine, \\ The Women and Children's Hospital of Qingdao, Qingdao, Shandong 266033, P.R. China
}

Received May 30, 2016; Accepted April 11, 2017

DOI: $10.3892 /$ etm.2018.5927

\begin{abstract}
The aim of the present study was to investigate the expression of microRNA (miR)-663 and its regulatory effects on the pathogenesis of nasal polyposis in children. Nasal polyp tissue, as well as serum and peripheral blood eosinophils were collected from 35 children diagnosed with nasal polypectomy between August 2013 and August 2015. As a control, the inferior nasal concha, serum and peripheral blood eosinophils were collected from 46 patients with nasal septal deviation complicated by inferior turbinate hypertrophy or patients with simple inferior turbinate hypertrophy who had undergone surgical removal of the inferior nasal concha. Reverse transcription-quantitative polymerase chain reaction (RT-qPCR) was used to measure the expression of miR-663 and transforming growth factor- $\beta 1$ (TGF- $\beta 1$ ) in the nasal polyp tissue, serum and peripheral blood eosinophils of patients with nasal polyposis and controls. Western blotting was used to measure the expression of TGF- $\beta 1$ protein in nasal tissue and eosinophils and an enzyme-linked immunosorbent assay was used to measure serum level of TGF- $\beta 1$ protein. A dual luciferase reporter assay was used to determine whether TGF- $\beta 1$ was a target gene of miR- 663 . Compared with the control group, levels of TGF- $\beta 1$ mRNA and protein were significantly increased in all three types of specimens from pediatric patients with nasal polyposis $(\mathrm{P}<0.05)$. miR-663 expression was significantly decreased in nasal polyp tissue and peripheral blood eosinophils $(\mathrm{P}<0.05)$. The dual luciferase reporter assay confirmed that TGF- $\beta 1$ was a target gene of miR-663. The current study suggests that the upregulation of TGF- $\beta 1$ may be associated with the downregulation of miR-663 in nasal polyposis in children. miR-663 may have regulatory effects on the pathogenesis of nasal polyposis by
\end{abstract}

Correspondence to: Professor Hailing Yu, Department of Otolaryngology, The Women and Children's Hospital of Qingdao, 217 Liaoyang West Road, Qingdao, Shandong 266033, P.R. China E-mail: ewd333@126.com

Key words: nasal polyposis, microRNA-663, transforming growth factor- $\beta 1$, eosinophils regulating TGF- $\beta 1$ and may be developed as a genetic marker of nasal polyposis in children.

\section{Introduction}

Nasal polyps are chronic inflammatory lesions located in the nasal cavity or sinus mucosa. Previous studies have classified nasal polyposis as a subtype or progressive stage of chronic sinusitis (1-3). Epidemiological surveys demonstrated that $2-4 \%$ of the global population was affected by nasal polyposis in 2003 (4-6). Nasal polyposis poses a threat to the health and quality of life of patients, particularly in pediatric patients $(7,8)$. Nasal polyposis in pediatric patients may induce constriction of the nasal cavity and nasal meatus, which may cause difficulties in postoperative cleanup and increase the susceptibility of patients to respiratory infections (9).

Among the three isoforms of transforming growth factor $\beta$ (TGF- $\beta$ ), TGF- $\beta 1$ is the isoform predominantly expressed in nasal polyposis (10). TGF- $\beta 1$ primarily originates from inflammatory cells, including eosinophils, macrophages and epithelial cells (11). TGF- $\beta 1$ serves a key role in cell biological behaviors, including extracellular matrix formation and fibrosis, epithelial cell metaplasia, vascularization, immune hypersensitivity, embryonic development, cell senescence and apoptosis (12). Among these functions, promoting the formation of the extracellular matrix is the most prominent feature of TGF- $\beta 1(13,14)$. TGF- $\beta 1$ is one of the important signaling molecules secreted by inflammatory cells during inflammation $(15,16)$. However, the role of TGF- $\beta 1$ in the inflammation and regulatory mechanisms of pathogenesis in nasal polyposis in children remains unknown. It has been reported that microRNA-663 (miR-663) is an upstream regulator of TGF- $\beta 1$ and inhibits the development of papillary thyroid carcinoma and liver cancer through regulating TGF- $\beta 1$ (17,18). However, whether miR-663 regulates TGF- $\beta 1$ in nasal polyposis of children is unknown.

The aim of the present study was to measure the expression of TGF- $\beta 1$ mRNA and protein in nasal polyp tissue, serum and peripheral blood eosinophils using reverse transcription-quantitative polymerase chain reaction, western blotting, bioinformatics prediction analysis and ELISA in pediatric patients with nasal polyposis. Additionally, the association between the expression of TGF- $\beta 1$ and miR-663 was verified 
in order to evaluate their roles in the pathogenesis of nasal polyposis in children.

\section{Patients and methods}

Participant recruitment and selection criteria. Nasal polyp tissue, serum and peripheral blood eosinophils were collected from 35 pediatric patients with nasal polyposis who had undergone nasal polypectomy in the Department of Otolaryngology in the Women and Children's Hospital of Qingdao (Qingdao, China) between August 2013 and August 2015. These patients were part of the patient group and there were 16 males and 19 females with a median age of 11 years (age range, 7-14 years). The inclusion criteria and exclusion criteria for patients were as previously described (19). The diagnosis of nasal polyposis in all patients was confirmed by pathologists. The inferior nasal concha, serum and peripheral blood eosinophils were collected from 46 patients with nasal septal deviation complicated by inferior turbinate hypertrophy or patients with simple inferior turbinate hypertrophy undergoing surgical removal of inferior nasal concha. These patients were part of the control group and there were 18 males and 28 females with a median age of 10 years (age range, 6-14 years). Patients in the two groups were excluded if they were diagnosed with infection, diabetes, cancer, or autoimmune disease, or exhibited complications involving the heart, liver and kidney. Prior written informed consent was obtained from the patients' families and the present study was approved by the Ethics Review Board of the Women and Children's Hospital of Qingdao (Qingdao, China).

Reagents and antibodies. The miRcute miRNA Isolation kit, miRcute miRNA cDNA first strand synthesis kit, miRcute miRNA quantitative fluorescence detection kit (FP401), SuperReal PreMix (SYBR Green; FP204) and TIANScript II cDNA first strand synthesis kit (KR107) were all purchased from Tiangen Biotech Co., Ltd. (Beijing, China). The rabbit anti-human TGF- $\beta 1$ antibody (ab92486) and rabbit anti-human $\beta$-actin antibody (ab6276) were purchased from Abcam (Cambridge, MA, USA). TRIzol reagent (10606ES60; Shanghai YISHENG Biology Technology Co., Ltd., Shanghai, China), goat anti-rabbit secondary antibody (ab6721; Abcam), BCA Protein assay kit (RTP7102, Beijing Zhongke Ruitai, Beijing, China) and serum RNA extraction kit miRNeasy Serum/Plasma kit (JL217184; Guangzhou Jianlun Biological Technology Co., Ltd., Guangzhou, China) were also used in the current study. A TGF- $\beta 1$ ELISA kit (ab100674; Abcam), enhanced chemiluminence (ECL) solution (FDO0142; Nanjing Aoduofuni Biotechnology Co., Ltd., Nanjing, China), miR-663 mimics (Guangzhou Ruibo Biological Technology Co., Ltd., Guangzhou, China) were purchased. Anti-cluster of differentiation (CD)16 immunomagnetic beads (YB-22355) were purchased from Yubo Biological Technology Co., Ltd., (Shanghai, China). Ficoll-Hypaque separation medium (Cedarlane Laboratories, Burlington, Canada) including Solution A (12\%, density: 1.090), Solution B (9.0\%, density: 1.076) and Solution C (6.4\%, density: 1.065) was also used in the current study.

Specimen collection. Nasal polyp tissues were collected during surgery and frozen in liquid nitrogen. Peripheral blood was collected from all patients and stored at $-20^{\circ} \mathrm{C}$ and the serum was isolated by centrifugation at $400 \mathrm{x} \mathrm{g}$ for $10 \mathrm{~min}$ at $4^{\circ} \mathrm{C}$. Peripheral blood eosinophils were isolated using Magnetic activated cell sorting (MACS). Peripheral blood $(100 \mu \mathrm{l})$ was collected and EDTA anticoagulant $(0.1 \mathrm{~mol} / \mathrm{l}$, $\mathrm{pH} 7.7)$ and a specific dye for eosinophils $(0.9 \mathrm{ml})$ were added. Eosinophils were then counted using an ECLIPSE TS100 (Nikon Corporation, Tokyo, Japan) at a magnification of x100. The remaining blood was diluted with $6 \%$ dextran (1:5) and placed in a water bath at $37^{\circ} \mathrm{C}$ for $40 \mathrm{~min}$. The supernatant was centrifuged at $600 \mathrm{x} \mathrm{g}$ at room temperature for $10 \mathrm{~min}$ and the leukocyte specimen was collected. Subsequently, the leukocyte specimen was mixed with solutions A, B and C of the Ficoll-Hypaque separation medium and centrifuged at $800 \mathrm{x}$ g for $20 \mathrm{~min}$ at room temperature. Cell suspensions were divided into four layers and the eosinophil layer was aspirated and washed twice with PBS $(0.01 \mathrm{~mol} / \mathrm{l})$. The total number of cells including eosinophils was counted using an ECLIPSE TS100 (Nikon Corporation). Four fields under x100 magnification were randomly selected for cell counting. Anti-CD16 MicroBeads $\left(20 \mu \mathrm{l}\right.$, pre-cooled at $\left.4^{\circ} \mathrm{C}\right)$ were added to $1 \times 10^{7}$ total cells, mixed well and incubated at $6-12^{\circ} \mathrm{C}$ for $15 \mathrm{~min}$. The cell mixture was applied twice to the MACS column (Miltenyibiotec, Bergisch Gladbach, Germany). The magnetically anti-CD16 labeled cells (neutrophils) were arrested in the separation column while unlabeled cells (eosinophils) passed through the column. Isolated eosinophils were collected and washed with PBS $(0.01 \mathrm{~mol} / \mathrm{l})$. Cells were incubated in an atmosphere containing $5 \% \mathrm{CO}_{2}$ at $37^{\circ} \mathrm{C}$. The eosinophils were counted at every step and stained with Trypan blue at room temperature for $3 \mathrm{~min}$ to evaluate cell activity.

Reverse transcription-quantitative polymerase chain reaction $(R T-q P C R)$. Frozen tissues (pulverized in liquid nitrogen) were lysed thoroughly using $1 \mathrm{ml}$ TRIzol reagent and total RNA was extracted using the phenol chloroform method (20). Total RNA was extracted using the serum RNA extraction kit miRNeasy Serum/Plasma kit. Gel electrophoresis and spectrophotometry were conducted to measure the optical density (OD) 260/280 ratio and measure the concentration and quality of RNA. Total RNA $(1 \mu \mathrm{g})$ was reverse transcribed into cDNA using the TIANScript II cDNA first strand synthesis kit according to the manufacturer's protocols. The SuperReal PreMix (SYBR Green) was used during qPCR with the following primers: TGF- $\beta 1$, forward, 5 '-GGACACCAACTA TTGCTTCAG-3' 160 base pairs (bp) and reverse, 5'-TCC AGACTCCAAATGTAG-3'; $\beta$-actin, forward, 5'-TTCCAG CCTTCCTTCCTGG-3' 224 bp and reverse, 5'-TTGCGCTCA GGAGGAGGAAT-3'. The reaction conditions of qPCR were as follows: Pre-denaturation at $95^{\circ} \mathrm{C}$ for $2 \mathrm{~min}, 30$ cycles of denaturation at $94^{\circ} \mathrm{C}$ for $45 \mathrm{sec}$, annealing at $55^{\circ} \mathrm{C}$ for $55 \mathrm{sec}$, extension at $72^{\circ} \mathrm{C}$ for $1 \mathrm{~min}$ and a final cycle at $72^{\circ} \mathrm{C}$ for $10 \mathrm{~min}$. Relative quantification of TGF- $\beta 1$ was calculated as the ratio of TGF- $\beta 1 / \beta$-actin using the $2^{-\Delta \Delta \mathrm{Cq}}$ method (21).

The miRcute miRNA Isolation kit was used to isolate miR-663 from cells. An miRcute miRNA cDNA first strand synthesis kit was used to obtain cDNA. To detect miR-663, the miRcute miRNA quantitative fluorescence detection kit was used and U6 was the internal control. The primers used were as follows: U6, forward, 5'-CTCGCTTCGGCA 
GCACA-3' and reverse, 5'-AACGCTTCACGAATTTGC GT-3'; miR-663, forward, 5'-TGCGGAGGCGGGGCGCCG CGGG-3' and reverse, 5'-CCAGTGCAGGGTCCGAGGT-3'. The reaction conditions were as follows: Pre-denaturation at $95^{\circ} \mathrm{C}$ for $3 \mathrm{~min}, 40$ cycles of denaturation at $94^{\circ} \mathrm{C}$ for $30 \mathrm{sec}$, annealing at $56^{\circ} \mathrm{C}$ for $30 \mathrm{sec}$ and extension at $72^{\circ} \mathrm{C}$ for $20 \mathrm{sec}$. The ratio of miR-663/U6 was calculated using the $2^{-\Delta \Delta \mathrm{Cq}}$ method (21).

Western blotting. The total proteins were extracted using a protein extraction kit (310003; BestBio Company, Shanghai, China) following the manufacturers' instructions. The concentration of protein was measured using the BCA protein assay kit. Protein samples (30 $\mu \mathrm{g} / \mathrm{lane})$ were analyzed using $10 \%$ SDS-polyacrylamide gel electrophoresis and transferred to a PVDF membrane. The membrane was then blocked with 5\% non-fat milk for $1 \mathrm{~h}$ at room temperature. Primary antibodies against TGF- $\beta 1(1: 500)$ and $\beta$-actin $(1: 5,000)$ were added and incubated at $4{ }^{\circ} \mathrm{C}$ overnight. Goat anti-rabbit secondary antibody (1:3,000; cat no. ab6721; Abcam) were added and incubated at room temperature for $1 \mathrm{~h}$. The PVDF membrane was placed in the ECL detection system and imaged using Image Lab Software version 3.0 (Bio-Rad Laboratories, Inc., Hercules, CA, USA) to acquire and analyze imaging signals of protein bands. The relative density of target protein was defined as the ratio of gray values between the target protein and $\beta$-actin.

ELISA. The TGF- $\beta 1$ ELISA kit was used to perform ELISA. ELISA plates were classified into standard, serum and blank wells. Standard samples $(50 \mu \mathrm{l})$ and serum (10 and $40 \mu \mathrm{l}$ sample diluent) were added to the wells, whereas no solution was added to blank wells. Subsequently, horseradish peroxidase-labeled goat anti-rabbit secondary antibody (cat no. ab6721; Abcam; $100 \mu \mathrm{l}$ ) was added to each well and incubated at $37^{\circ} \mathrm{C}$ for $1 \mathrm{~h}$. The plates were then washed 5 times and substrates A $(50 \mu \mathrm{l})$ and B $(50 \mu \mathrm{l})$, respectively, were added. Following incubation for $15 \mathrm{~min}$ at $37^{\circ} \mathrm{C}$, stop solution $(50 \mu \mathrm{l})$ was added. The absorbance value at OD $450 \mathrm{~nm}$ was measured within $15 \mathrm{~min}$ on the Multiskan FC microplate reader (Thermo Scientific Inc., Waltham, MA, USA).

Bioinformatics predictions of upstream-regulatory miR for TGF- $\beta 1$. Bioinformatics prediction is one of the major approaches for functional studies of miR. To further determine the regulatory mechanism of upstream miRs in the pathogenesis of nasal polyposis, target gene prediction software, including miRanda (http://www.microma. org/rnicroma/home.do), TargetScan 2.0 (www.targetscan.org) and PicTar (http://pictar.mdc-berlin.de/) were used to identify the potential genes that have regulatory effects on TGF- $\beta 1$. The procedures were performed according to the instructions on each website.

Dual-luciferase reporter assay. The wild-type and mutant type 3'-untranslated region (UTR) in TGF- $\beta 1$ were chemically synthesized in vitro. The wild-type and mutant type 3'-UTR were added to the restriction enzyme cleavage sites of SpeI and HindIII and cloned into a pMIR-REPORT luciferase reporter plasmid (cat no. AM5795; Ambion; Thermo Fisher
Scientific, Inc.). 293T cells (Cobioer Biosciences Co., Ltd., Nanjing, China) were co-transfected with plasmid with wild type 3'-UTR $(0.8 \mu \mathrm{g})$ and miR-663 mimics $(100 \mathrm{nM})$, or co-transfected with mutant type 3'-UTR $(0.8 \mu \mathrm{g})$ and miR-663 mimics (100 nM) (synthesized by Sangon Biotech Co., Ltd., Shanghai, China). 293T cells transfected with empty plasmid were considered to be negative controls. Cells were incubated at $37^{\circ} \mathrm{C}$ for $24 \mathrm{~h}$ and then lysed. Fluorescence was measured using a GloMax ${ }^{\circledR}$ 20/20 luminometer according to the instructions of the dual luciferase reporter system kit (Promega Corporation, Madison, WI, USA). Renilla fluorescent activity was considered as an internal reference.

Statistical analysis. All data were analyzed using SPSS 18.0 software (SPSS, Inc., Chicago, IL, USA). Measurement data were expressed as mean \pm standard deviation. Normality tests were conducted for all data and a $\mathrm{T}$ test was used for comparison between two independent groups. One-way analysis of variance (ANOVA) was used to compare data of more than two independent groups. For data with homogeneity of variance, least significant difference and Student-Newman-Keuls methods were used following ANOVA; otherwise, Tamhane's T2 or Dunnett's T3 method was used. $\mathrm{P}<0.05$ was considered to indicate a statistically significant difference.

\section{Results}

mRNA expression of TGF- $\beta 1$ in different specimens. RT-qPCR was performed to detect the expression of TGF- $\beta 1$ mRNA in different specimens. The results demonstrated that, compared with controls, the expression of TGF- $\beta 1$ mRNA was significantly upregulated in nasal polyp tissue $(\mathrm{P}<0.01$; Fig. 1A), serum $(\mathrm{P}<0.05$; Fig. 1B) and peripheral blood eosinophils $(\mathrm{P}<0.01$; Fig. $1 \mathrm{C})$ of pediatric patients with nasal polyposis. These results indicate that TGF- $\beta 1$ may serve an important role in the pathogenesis of nasal polyposis in children.

Expression of TGF- $\beta 1$ protein in nasal polyp tissue and eosinophils. Western blotting was performed to detect the expression of TGF- $\beta 1$ protein in nasal polyp tissue and peripheral blood eosinophils. The results demonstrated that, compared with controls, expression of TGF- $\beta 1$ was significantly upregulated in the nasal polyp tissue (Fig. 2A) and peripheral blood eosinophils $(\mathrm{P}<0.01$; Fig. 2B) of pediatric patients with nasal polyposis. To confirm these results, TGF- $\beta 1$ levels in serum were measured using ELISA. Compared with controls, levels of TGF- $\beta 1$ protein were significantly upregulated in the serum of pediatric patients with nasal polyposis $(\mathrm{P}<0.05$; Fig. $2 \mathrm{C}$ ). These results suggest that changes in the expression of TGF- $\beta 1$ protein are positively associated with changes in the expression of TGF- $\beta 1$ mRNA. Thus, upregulated TGF- $\beta 1$ levels may have regulatory effects on the pathogenesis of nasal polyposis in children.

Expression of miR-663 expression in different specimens. To detect the level of miR-663 in nasal polyp tissue, serum and peripheral blood eosinophils of pediatric patients with nasal polyposis, RT-qPCR was performed. As presented in Fig. 3, the expression of miR-663 was significantly decreased in 

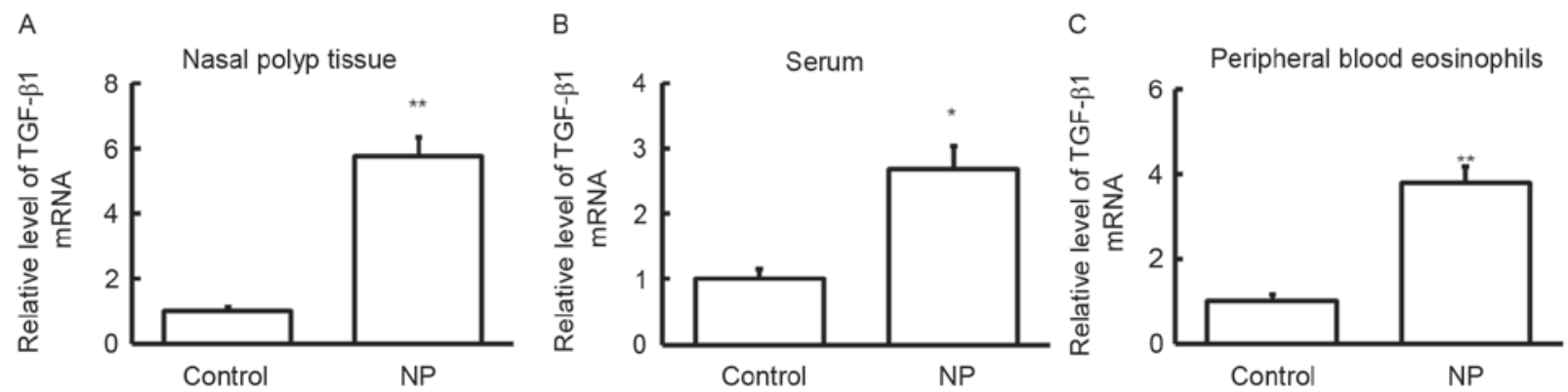

Figure 1. Analysis of TGF- $\beta 1$ mRNA expression. The expression of TGF- $\beta 1$ mRNA in (A) nasal polyp tissue, (B) serum and (C) peripheral blood eosinophils was measured using reverse transcription-quantitative polymerase chain reaction. All data are presented as the mean + standard deviation. ${ }^{*} \mathrm{P}<0.05$ and ${ }^{* *} \mathrm{P}<0.01$ vs. Control. NP, patients with nasal polyposis; TGF- $\beta 1$, transforming growth factor- $\beta 1$.

A

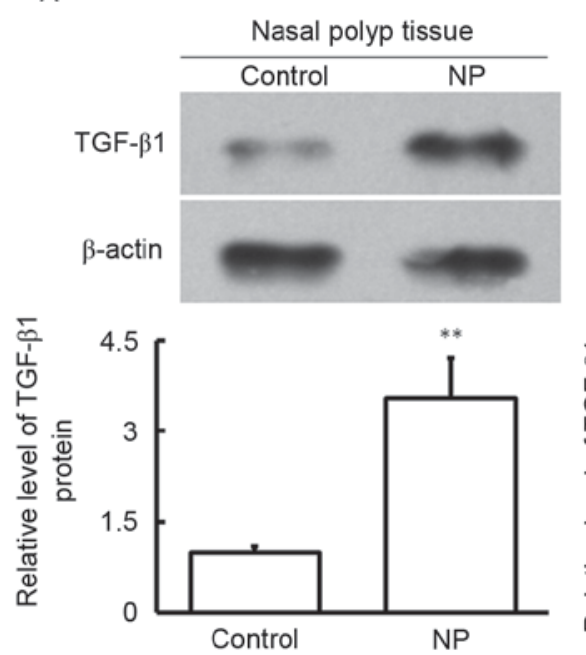

B

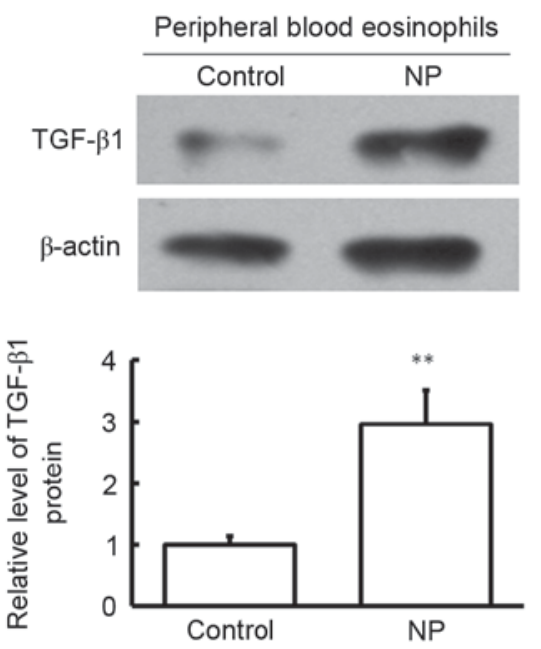

C

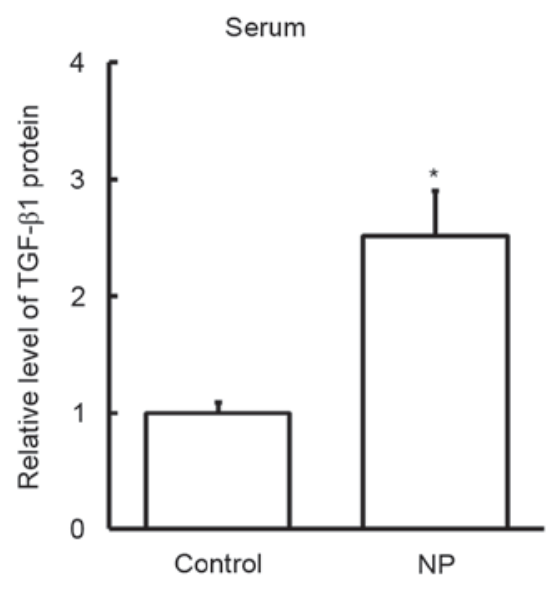

Figure 2. Analysis of TGF- $\beta 1$ protein expression. The expression of TGF- $\beta 1$ in (A) nasal polyp tissue and (B) peripheral blood eosinophils was measured by western blotting. The protein expression of TGF- $\beta 1$ in (C) serum was measured using ELISA. Data are presented as the mean + standard deviation. ${ }^{*} \mathrm{P}<0.05$ and ${ }^{* *} \mathrm{P}<0.01$ vs. Control. TGF- $\beta 1$, transforming growth factor- $\beta 1$; NP, patients with nasal polyposis.

A

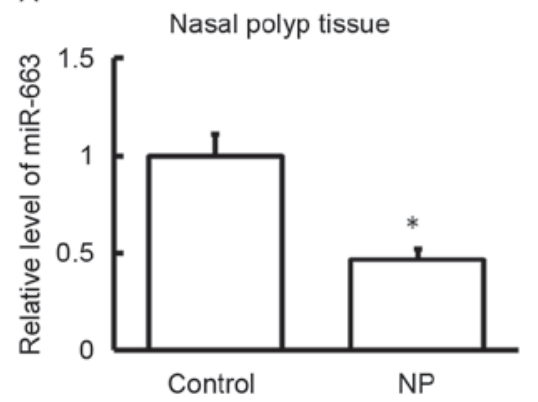

B

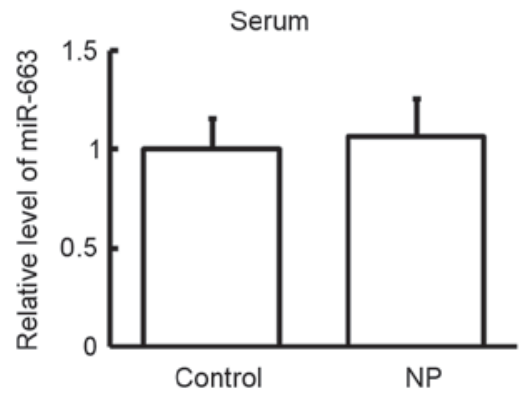

C

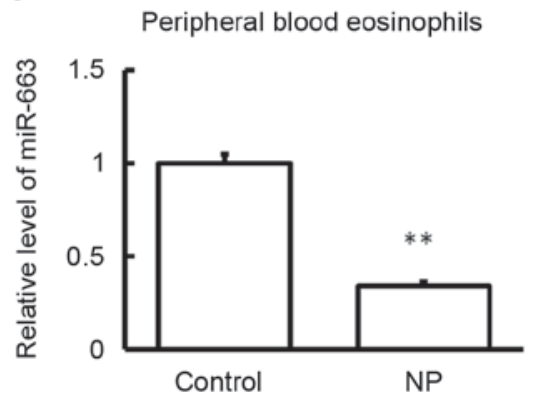

Figure 3. Analysis of miR-663 expression. miR-663 expression in (A) nasal polyp tissue, (B) serum and (C) peripheral blood eosinophils was detected using reverse transcription-quantitative polymerase chain reaction. All data are presented as the mean + standard deviation. ${ }^{*} \mathrm{P}<0.05$ and ${ }^{* *} \mathrm{P}<0.01$ vs. Control. NP, patients with nasal polyposis; miR-663, microRNA-663.

the nasal polyp tissue $(\mathrm{P}<0.05$; Fig. $3 \mathrm{~A})$ and peripheral blood eosinophils $(\mathrm{P}<0.01$; Fig. $3 \mathrm{C})$ of pediatric patients with nasal polyposis compared with controls. However, there was no significant difference in miR-663 expression in the serum of patients with nasal polyposis compared with controls $(\mathrm{P}>0.05$; Fig. 3B). These results suggest that miR-663 may serve a role in the pathogenesis of nasal polyposis.
Dual-luciferase reporter assay. To identify whether TGF- $\beta 1$ is a target of miR-663, a bioinformatics prediction was conducted. It was determined that miR-663 is one of the regulatory genes for TGF- $\beta 1$ and the binding sequence is presented (Fig. 4A). A dual-luciferase reporter assay was conducted to verify this result. Following co-transfection with miR-663 mimics and wild-type 3'UTR, the fluorescence values 
A

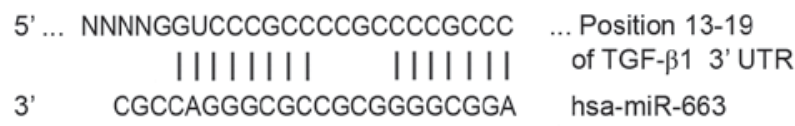

B

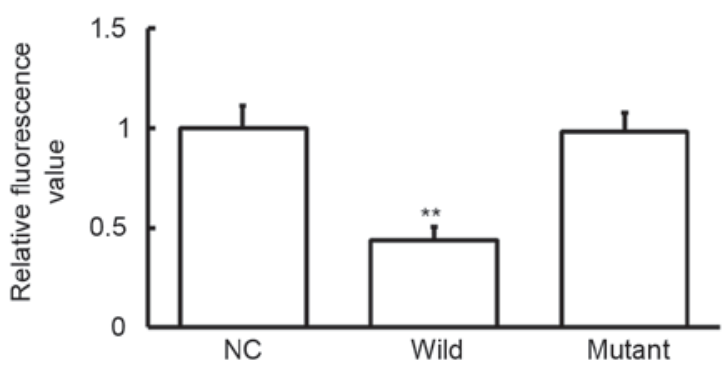

Figure 4. The regulating effects of miR-663 on the expression of TGF- $\beta 1$. (A) Bioinformatics prediction result. (B) Result of dual-luciferase reporter assay. All data are presented as the mean + standard deviation. ${ }^{* *} \mathrm{P}<0.01 \mathrm{vs}$. NC. TGF- $\beta 1$, transforming growth factor- $\beta 1$; NP, patients with nasal polyposis; NC, negative control; miR-663, microRNA-663; 3'UTR, 3'untranslated region.

decreased significantly $(\mathrm{P}<0.05$; Fig. 4B). By contrast, there was no significant difference in the fluorescence value of the mutant group compared with the negative control (Fig. 4B). These findings suggest that miR-663 binds to the 3'-UTR of TGF- $\beta 1$ to regulate TGF- $\beta 1$ expression.

\section{Discussion}

In the present study, the expression of TGF- $\beta 1$ and its upstream gene miR-663 were detected in nasal polyp tissue, serum and peripheral blood eosinophils of children with nasal polyposis. A dual-luciferase reporter assay was performed to confirm the binding of miR-663 and TGF- $\beta 1$ and to evaluate whether miR-663 contributes to the pathogenesis of nasal polyposis.

Nasal polyposis is a type of refractory rhinologic disease in children characterized by an unknown pathogenesis, persistent activity and difficulty of treatment (22). In the past, it was thought that nasal polyposis was caused by an allergic reaction (23). However, recent studies suggest that the clinical features of nasal polyposis are similar to those of eosinophilic non-allergic rhinitis $(24,25)$. The concept of eosinophilic non-allergic rhinitis was proposed in 1979 and it was suggested that eosinophils may serve a key role in inflammation, similar to their role in chronic sinusitis. However, this hypothesis cannot explain the accumulation of eosinophils that occurs in nasal polyp tissue. Previous studies have investigated the mechanism of eosinophil accumulation in nasal polyposis (26-28), which emphasizes nasal polyps as the products of inflammatory reactions, regulated by cytokines in the local microenvironment. Nasal polyp cells, including epithelial cells and fibroblasts, can secrete cytokines that stimulate and prolong the cell cycle of inflammatory cells, particularly eosinophils (29). Furthermore, eosinophils themselves are able to synthesize and secrete important inflammatory cytokines and regulatory factors, which in turn can stimulate inflammatory cell proliferation (30).

TGF- $\beta 1$ is produced by eosinophils. Studies have demonstrated that TGF- $\beta 1$ promotes the production of interleukin (IL)-6 from human fibroblasts and the growth of fibroblasts and osteoblasts by regulating the transcription of IL-6 (31-33). TGF- $\beta 1$ may promote the formation of the extracellular matrix and serve an important role in cell morphogenesis, proliferation and differentiation in muscle tissue (34-36). In vivo studies have demonstrated that the upregulation of TGF- $\beta 1$ in local tissue can promote wound healing and the formation of typical granulation tissue (37). In the present study, TGF- $\beta 1$ expression was upregulated in all specimens taken from pediatric patients with nasal polyposis. This upregulation may promote the proliferation of fibroblasts and the formation of typical granulation tissue; these effects are closely associated with the formation of nasal polyposis $(38,39)$. Thus, TGF- $\beta 1$ may promote the pathogenesis of nasal polyposis.

The regulation mechanism of TGF- $\beta 1$ expression has not been fully elucidated. Studies have suggested that nemo-like kinase and Smad protein may be regulate TGF- $\beta 1(40,41)$. In addition, specific miRs can negatively regulate the expression of TGF- $\beta 1$ by cleaving TGF- $\beta 1$ mRNA and inhibiting its translation. This inhibitory effect is important in maintaining the balance of the physiological and pathological states of the human body $(42,43)$. Recent studies have demonstrated that TGF- $\beta 1$ mRNA regulates miR in nasal polyposis and it was determined that miR-1343 may regulate the expression of TGF- $\beta 1$ receptors (44-46). In the current study, bioinformatic predictions revealed that miR-663 is an upstream miR, which may have regulatory effects on TGF- $\beta 1$ expression. The results also demonstrated that levels of miR-663 decrease following the upregulation of TGF- $\beta 1$ mRNA and protein. Furthermore, the results of the dual-luciferase reporter assay determined that miR-663 contributes to the targeted regulation of TGF- $\beta 1$ by binding to the 3'-UTR of TGF- $\beta 1$ and ultimately impacts on the pathological features of nasal polyposis. However, in the current study, serum levels of miR-663 did not change markedly, even though levels of serum TGF- $\beta 1$ increased. It was thus speculated that the elevation of TGF- $\beta 1$ was primarily caused by the abundant release of inflammatory cells rather than the downregulation of miR-663.

In conclusion, the present study demonstrated that miR-663 serves important biological functions in the regulation of TGF- $\beta 1$ gene expression and the onset and development of nasal polyposis. The results of the current study may therefore provide experimental evidence for the prevention and treatment of pediatric patients with nasal polyposis in clinical practice.

\section{Acknowledgements}

The present study was supported by a grant from the Natural Science Foundation of Shandong Province of China (grant no. ZR2013HM024). 


\section{References}

1. Bachert C, Zhang N, van Zele T and Gevaert P: Chronic rhinosinusitis: From one disease to different phenotypes. Pediatr Allergy Immunol 23 (Suppl 22): S2-S4, 2012.

2. Bachert C, Mannent L, Naclerio RM, Mullol J, Ferguson BJ, Gevaert P, Hellings P, Jiao L, Wang L, Evans RR, et al: Effect of subcutaneous dupilumab on nasal polyp burden in patients with chronic sinusitis and nasal polyposis: A randomized clinical trial. JAMA 315: 469-479, 2016

3. Neubauer PD, Schwam ZG and Manes RP: Comparison of intranasal fluticasone spray, budesonide atomizer, and budesonide respules in patients with chronic rhinosinusitis with polyposis after endoscopic sinus surgery. Int Forum Allergy Rhinol 6: 233-237, 2016.

4. Johansson L, Akerlund A, Holmberg K, Melén I and Bende M: Prevalence of nasal polyps in adults: The Skövde population-based study. Ann Otol Rhinol Laryngol 112: 625-629, 2003

5. We J, Lee WH, Tan KL, Wee JH, Rhee CS, Lee CH, Ahn S, Lee JH and Kim JW: Prevalence of nasal polyps and its risk factors: Korean national health and nutrition examination survey 2009-2011. Am J Rhinol Allergy 29: e24-e28, 2015.

6. Feng S, He Q, Fan Y, Mi J, Guo L, Hong H and Li H: Nasal endoscopic findings and nasal symptoms in patients with asthma: A clinical study from a rhinological perspective. Allergol Immunopathol (Madr) 43: 42-47, 2015.

7. Fetta M, Tsilis NS, Segas JV, Nikolopoulos TP and Vlastarakos PV: Functional endoscopic sinus surgery improves the quality of life in children suffering from chronic rhinosinusitis with nasal polyps. Int J Pediatr Otorhinolaryngol 100: 145-148, 2017.

8. Weber SAT, Iyomasa RM, Correa CC, Florentino WNM and Ferrari GF: Nasal polyposis in cystic fibrosis: Follow-up of children and adolescents for a 3-year period. Braz J Otorhinolaryngol 83: 677-682, 2017.

9. Veloso-Teles R and Cerejeira R: Endoscopic sinus surgery for chronic rhinosinusitis with nasal polyps: Clinical outcome and predictive factors of recurrence. Am J Rhinol Allergy 31: 56-62, 2017.

10. Park IH, Um JY, Hong SM, Cho JS, Lee SH, Lee SH and Lee HM: Metformin reduces TGF- $\beta 1$-induced extracellular matrix production in nasal polyp-derived fibroblasts. Otolaryngol Head Neck Surg 150: 148-153, 2014.

11. Piersma B, Bank RA and Boersema M: Signaling in Fibrosis: TGF- $\beta$, WNT, and YAP/TAZ Converge. Front Med (Lausanne) 2: $59,2015$.

12. Castellone MD and Laukkanen MO: TGF-beta1, WNT, and SHH signaling in tumor progression and in fibrotic diseases. Front Biosci (Schol Ed) 9: 31-45, 2017.

13. Poniatowski LA, Wojdasiewicz P, Gasik R and Szukiewicz D: Transforming growth factor Beta family: Insight into the role of growth factors in regulation of fracture healing biology and potential clinical applications. Mediators Inflamm 2015: 137823, 2015.

14. Vadon-Le Goff S, Hulmes DJ and Moali C: BMP-1/tolloid-like proteinases synchronize matrix assembly with growth factor activation to promote morphogenesis and tissue remodeling. Matrix Biol 44-46:14-23, 2015.

15. Richter K, Konzack A, Pihlajaniemi T, Heljasvaara R and Kietzmann T: Redox-fibrosis: Impact of TGF $\beta 1$ on ROS generators, mediators and functional consequences. Redox Biol 6: 344-352, 2015.

16. Lafyatis $\mathrm{R}$ : Transforming growth factor $\beta$-at the centre of systemic sclerosis. Nat Rev Rheumatol 10: 706-719, 2014

17. Huang Y, Liu J, Fan L, Wang F, Yu H, Wei W and Sun G: miR-663 overexpression induced by endoplasmic reticulum stress modulates hepatocellular carcinoma cell apoptosis via transforming growth factor beta 1. Onco Targets Ther 9: 1623-1633, 2016.

18. Wang Z, Zhang H, Zhang P, Dong W and He L: MicroRNA-663 suppresses cell invasion and migration by targeting transforming growth factor beta 1 in papillary thyroid carcinoma. Tumour Biol 37: 7633-7644, 2016.

19. Fokkens W, Lund V and Mullol J; European Position Paper on Rhinosinusitis and Nasal Polyps Group: EP3OS 2007: European position paper on rhinosinusitis and nasal polyps 2007. A summary for otorhinolaryngologists. Rhinology 45: 97-101, 2007.

20. Qin JJ, Lu ZY, Jiao ZP, Zhu XJ, Wang YX and Tang H: Modified TRIzol method for RNA and DNA co-extraction from blood. Fa Yi Xue Za Zhi 29: 209-211, 2013 (In Chinese).
21. Livak KJ and Schmittgen TD: Analysis of relative gene expression data using real-time quantitative PCR and the 2(-Delta Delta C(T)) method. Methods 25: 402-408, 2001.

22. Hulse KE, Stevens WW, Tan BK and Schleimer RP: Pathogenesis of nasal polyposis. Clin Exp Allergy 45: 328-346, 2015.

23. 23 Bernstein JM, Gorfien J and Noble B: Role of allergy in nasal polyposis: A review. Otolaryngol Head Neck Surg 113: 724-732, 1995.

24. Calus L, Devuyst L, Van Zele T, De Ruyck N, Derycke L, Bachert $\mathrm{C}$ and Gevaert P: The response to nasal allergen provocation with grass pollen is reduced in patients with chronic rhinosinusitis with nasal polyposis and grass sensitization. Clin Exp Allergy 46: 555-563, 2016.

25. Becker S, Rasp J, Eder K, Berghaus A, Kramer MF and Gröger M: Non-allergic rhinitis with eosinophilia syndrome is not associated with local production of specific $\mathrm{IgE}$ in nasal mucosa. Eur Arch Otorhinolaryngol 273: 1469-1475, 2016.

26. Fokkens W, Lund V and Mullol J; European Position Paper on Rhinosinusitis and Nasal Polyps group: European position paper on rhinosinusitis and nasal polyps 2007. Rhinol Suppl 20: 1-136, 2007.

27. Fundová P, Funda DP, Kovar D, Holy R, Navara M and Tlaskalová-Hogenová $H$ : Increased expression of chemokine receptors CCR 1 and CCR3 in nasal polyps: Molecular basis for recruitment of the granulocyte infiltrate. Folia Microbiol (Praha) 58: 219-224, 2013

28. De Corso E, Baroni S, Romitelli F, Luca L, Di Nardo W, Passali GC and Paludetti G: Nasal lavage CCL24 levels correlate with eosinophils trafficking and symptoms in chronic sino-nasal eosinophilic inflammation. Rhinology 49: 174-179, 2011.

29. Pawankar R and Nonaka M: Inflammatory mechanisms and remodeling in chronic rhinosinusitis and nasal polyps. Curr Allergy Asthma Rep 7: 202-208, 2007.

30. Pawliczak R, Lewandowska-Polak A and Kowalski ML: Pathogenesis of nasal polyps: An update. Curr Allergy Asthma Rep 5: 463-471, 2005.

31. Janda K, Krzanowski M, Dumnicka P, Kusnierz-Cabala B, Krasniak A and Sulowicz W: Transforming growth factor beta 1 as a risk factor for cardiovascular diseases in end-stage renal disease patients treated with peritoneal dialysis. Clin Lab 60: 1163-1168, 2014.

32. Jin X, Ren S, Macarak E and Rosenbloom J: Pathobiological mechanisms of peritoneal adhesions: The mesenchymal transition of rat peritoneal mesothelial cells induced by TGF- $\beta 1$ and IL- 6 requires activation of Erk1/2 and Smad2 linker region phosphorylation. Matrix Biol 51: 55-64, 2016.

33. Xiao K, Jiao L, Cao S, Song Z, Hu C and Han X: Whey protein concentrate enhances intestinal integrity and influences transforming growth factor- $\beta 1$ and mitogen-activated protein kinase signalling pathways in piglets after lipopolysaccharide challenge. Br J Nutr 115: 984-993, 2016.

34. Cicha I, Yilmaz A, Klein M, Raithel D, Brigstock DR, Daniel WG, Goppelt-Struebe M and Garlichs CD: Connective tissue growth factor is overexpressed in complicated atherosclerotic plaques and induces mononuclear cell chemotaxis in vitro. Arterioscler Thromb Vasc Biol 25: 1008-1013, 2005.

35. Chen S, Liu J, Yang M, Lai W, Ye L, Chen J, Hou X, Ding H, Zhang W, Wu Y, et al: Fn14, a downstream target of the TGF- $\beta$ signaling pathway, regulates fibroblast activation. PLoS One 10: e0143802, 2015.

36. Kanaan RA, Aldwaik M and Al-Hanbali OA: The role of connective tissue growth factor in skeletal growth and development. Med Sci Monit 12: RA277-RA281, 2006.

37. Aström P, Pirilä E, Lithovius R, Heikkola H, Korpi JT, Hernández M, Sorsa T and Salo T: Matrix metalloproteinase- 8 regulates transforming growth factor- $\beta 1$ levels in mouse tongue wounds and fibroblasts in vitro. Exp Cell Res 328: 217-227, 2014.

38. Park SK, Jin YD, Park YK, Yeon SH, Xu J, Han RN, Rha KS and Kim YM: IL-25-induced activation of nasal fibroblast and its association with the remodeling of chronic rhinosinusitis with nasal polyposis. PLoS One 12: e0181806, 2017.

39. Shin JM, Park JH, Kang B, Lee SA, Park IH and Lee HM: Effect of doxycycline on transforming growth factor-beta-1-induced matrix metalloproteinase 2 expression, migration, and collagen contraction in nasal polyp-derived fibroblasts. Am J Rhinol Allergy 30: 385-390, 2016.

40. Xiao Z, Zhang J, Peng X, Dong Y, Jia L, Li H and Du J: The Notch $\gamma$-secretase inhibitor ameliorates kidney fibrosis via inhibition of TGF- $\beta / \mathrm{Smad} 2 / 3$ signaling pathway activation. Int $\mathrm{J}$ Biochem Cell Biol 55: 65-71, 2014. 
41. Shi Y, Ye K, Wu H, Sun Y, Shi H and Huo K: Human SMAD4 is phosphorylated at Thr9 and Ser138 by interacting with NLK. Mol Cell Biochem 333: 293-298, 2010.

42. Lazzarini R, Sorgentoni G, Caffarini M, Sayeed MA, Olivieri F, Di Primio R and Orciani M: New miRNAs network in human mesenchymal stem cells derived from skin and amniotic fluid. Int J Immunopathol Pharmacol 29: 523-528, 2016.

43. He X, Liu Z, Peng Y and Yu C: MicroRNA-181c inhibits glioblastoma cell invasion, migration and mesenchymal transition by targeting TGF- $\beta$ pathway. Biochem Biophys Res Commun 469: 1041-1048, 2016.
44. Stolzenburg LR, Wachtel S, Dang $H$ and Harris A: microRNA-1343 attenuates pathways of fibrosis by targeting the TGF- $\beta$ receptors. Biochem J 473: 245-256, 2016.

45. Shin JM, Park JH, Park IH and Lee HM: Pirfenidone inhibits transforming growth factor $\beta 1$-induced extracellular matrix production in nasal polyp-derived fibroblasts. Am J Rhinol Allergy 29: 408-413, 2015.

46. Yamin M, Holbrook EH, Gray ST, Busaba NY, Lovett B and Hamilos DL: Profibrotic transforming growth factor beta 1 and activin $\mathrm{A}$ are increased in nasal polyp tissue and induced in nasal polyp epithelium by cigarette smoke and Toll-like receptor 3 ligation. Int Forum Allergy Rhinol 5: 573-582, 2015. 